\title{
Chapter 6 \\ Ethno-Archaeological Investigation \\ to the "Straw and Bark Woven \\ Clothing" of Island Yi and Southern Man \\ in South of China and Southeast Asia
}

The complex and variant patterns of costume were important parts of the human cultures in the history. Generally, the early dress of human beings started from the non-woven fabrics such as grass leaves, barks, beast coats and fur, and other natural resources, and developed into woven cloth products of fiber thread with warp and weft structure. The clothing variants are the cultural representation of ethnic groups, showing the different costume traditions and cultural features. In the ethnic cultural system of Asia-Pacific region, the ancient clothing made of cotton, hemp, silk, and wool fibers in the inland region of East Asia centered on the Central Plains has a long tradition since prehistory, represented by the so-called "Clothing and Dressing Civilization" of Huaxia and Han nationality in its sinocentrism, while on the coast of southern China, Southeast Asia, and the Pacific Islands, the non-woven bark cloth of the indigenous Bai Yue (百越) system and Austronesian presents another distinctive costume culture (Ling, C.S. 1963).

According to historical literatures of ancient China, in the centralism vision of early Huaxia and the Han nationality, the costume culture of the indigenous people in southern China specialized in non-woven series, was "primitive" and "uncivilized", and "hetero-culture" of the "Clothing and Dressing Civilization" of Huaxia nationality. The section of "Nine States" (九州) in the chapter of "Tribute of the Yu Period” (禹贡) of the Book of Early History (Shangshu 尚书) records that Island Yi in Yangzhou state "wear straw clothes, make use of bark weavings, weave bamboo, use marine shells as decorations" (Ruan, Y. 2009: 312-313). The chapter of “Biography of Southern Barbarian Man (南蛮传)" in History of the Later Han Dynasty (Houhan Shu 后汉书) records that the descendants of "barbarian" Panhu (盘瓠) “weaving bark, then dyeing with weed seeds” (Fan, Y. 1965: 2829). Since Tang and Song dynasties there were a number of records of "straw and bark weaving" of the early indigenous people in southern China and Southeast Asia, generally referring to their unique clothing culture. Besides, these cultural connotations and work craft of the indigenous bark cloth in southern China and Southeast Asia recorded sporadically in ancient Chinese historical literatures, they also remain in modern ethnographies of the indigenous minorities of southern China, Southeast

C. Wu, The Prehistoric Maritime Frontier of Southeast China,

The Archaeology of Asia-Pacific Navigation 4,

https://doi.org/10.1007/978-981-16-4079-7_6 
Asia, and the Pacific, both of which are the important references for sketching the history of bark cloth costume since prehistory. This chapter will go through the historic outline of "straw and bark clothing" of indigenous peoples in Asia-Pacific region, by discussing the contents of "bark cloth" in the southern China and Southeast Asia in the Chinese historical records, comparing with the ethnographical investigation of bark-cloth weaving work craft in Adulan (都兰) tribe of Ami ethnic in Taiwan, and other related bark weaving heritages of Dai (傣) ethnic in Yunnan, Li (黎) ethnic in Hainan, Bru-vankieu people in Vietnam and Austronesian of Western Samoa, as well as complementing with the typological understanding on the bark cloth beaters of archaeological collections (Tang, C. 2000, 2003; Wu, C.M. 2009, 2010).

\section{1 "Straw and Bark Woven Clothing" of Island Yi Recorded in the Chinese History}

In the ancient geopolitical order of "Central Nation-Various States in Four Directions", the Central Nation of Huaxia continuously assimilated to the various "barbarian" states in "Four Directions" from center to periphery, including southward to its "Southeastern Direction" and from mainland to ocean. The cognition of “Southeastern Direction" and "Yangzhou" (扬州) in the centralism vision of the Huaxia and Han nationality was also gradually deepened and expanded, spatially from the south of the Yangtze River to south of Nanling (南岭) Mountain, the Lingnan (岭南), and even reached its "South of the South" in Southeast Asia. A series of "hetero" cultural landscapes of the "Straw Clothing and Bark Weaving" of ancient indigenous people of Southern Man or Bai Yue and Bai Pu (百誉) were recorded in the historical documents of Huaxia and Han nationality, from which we know the significant history of the dressing culture of indigenous peoples in the Asia-Pacific maritime region.

The chapter of "Tribute of the Yu Period (禹贡)" in the Book of Early History records varied landscapes and material cultures in the "Nine States" (九州) of the Nation, among them the "Island $Y i$ wearing straw clothes" was the most unique one. "The Yangzhou region is located near the Huaihai (淮海)...The barbarians on the islands pay tribute of gold, silver, copper, jade, ivories, skin, feather artifacts, and alike to the central empire. The Islands Yi wear straw clothes Huifu (卉服), make use of the bark weaving, weave bamboo, use marine shells as decorations, live along the rivers and seas" (Ruan, Y. 2009: 312-313). A number of historians annotated that "Huifu is the clothes made of grass, that is straw clothes. For the tropical climate in south, the islanders there weaved grass into cloth" (Shao, W. P. 1989). That is to say, the ancient indigenous people in the southeast coast wore non-woven clothes made of straw and bark.

"Biography of Southern Barbarian Man (南蛮传)" in History of the Later Han Dynasty records the totem legend of Southern Man and "weaving bark" of them. 
“In the early history, the Gaoxing (高辛) state was invaded by barbarian Quanrong (犬戎, the dog barbarian). Then the emperor posted a reward for getting the head of general Wu of Quanrong army by promising to award a great amount of gold, land, and betrothing the princess. At that time, emperor raised a dog with multicolored hair and was called Panhu (盘瓠). After the emperor's announcement, dog Panghu took the head of general $\mathrm{Wu}$ to report. All of the national ministers were surprised and the emperor was happy to marry his daughter to dog Panghu. Then dog Panhu brought the princess and left for the mountainous cave... The descendants of them wove bark then dyed with weed seeds to make use of multicolored clothes with a tail...They wore colorful clothes, spoke a different language, enjoyed staying in mountainous and cavern regions rather than the plain areas... Their descendants grew and were called barbarian Man Yi (蛮夷)" (Fan, Y. 1965: 2829). In this legend, the Southern Man's "weaving bark then dyeing with weed seeds" share the same patterns with straw and bark clothes of the Island $Y i$ of $\mathrm{Yu}$ period.

The chapter of the "History of Aristocratic Family of Gou Jian, the King of Yue" (越王句践世家) of the Records of the Historian (Shiji 史记) records: “The ancestor of Gou Jian, the king of the Yue state... where the local indigenous having the custom of cutting hair without hairpin, tattoo body and wearing straw clothes in the capital" (Sima, Q. 1959: 2099). "wearing straw clothes in the capital" obviously means that the culture of Gou Jian state was taken as very different from the "Clothing and Dressing Civilization" of Huaxia Nation.

Throughout the Middle Ages of ancient China, many indigenous peoples in the South were known for their "weaving" bark. The Chapter of "Cloth and Costume" (布帛部) in Vol. eight hundred and twenty of Imperial Encyclopaedia in Taiping Reign (Taiping Yulan 太平御览) cited from Records in Guangzhou (Guangzhou Ji 广州记) written by Gu Wei (顾微) states, “In Aling (阿林) county the local people half cut a kind of big tree to make it grew new branches, and peeled the log barks to weave into cloth, which was quite soft for wearing" (Li, F. et al. 2008: book 900: 313). The section of “Straw Clothes" (Huifu 卉服) in the Nice Works of Southern China (Chiya 赤雅) written by Kuang Lu (广露) in the Ming Dynasty states, “The straw and bark that can be made to clothes in the South are called Huifu, that is straw and bark clothes. The clothes made of wood barks vary as Gou Mang (勾芒) cloth, Hong Jiao (红蕉 Musa coccinea) cloth and Ruo Xi (弱锡) cloth made of ramie" (Kuang, L. 1985: 4). This straw and bark clothes "Huifu" verify the essence of Huifu of Island Yi in Yu period recorded in Book of Early History.

The indigenous peoples of Hainan and Taiwan were the two most famous ethnic groups making use of bark cloth in ancient history. The ancient indigenous people in states of Dan Er (儋耳) and Diao Ti (雕题) in Hainan island belonged to one of the branches of Luo Yue (骆越), known as Li (黎) and Li Dong (黎峒) since the Medieval Age of ancient China. The section of "Dan (儋) State" in the Vol. One Hundred and Sixty-nine in Geographical Record of the World in Taiping Reign (Tai Ping Huang Yu Ji 太平寰宇记) records that “The (state) of Dan Er recorded in the Classic of the Mounts and Seas (Shanhai Jing 山海经) also called Li Er (离耳). The local people call the mountain as $L i$ (黎) and the people living in the mountains are called wild barbarians, that is Wild Li (生黎). They like butchering and take the 
tooth of the killed to make laces, wearing them on the heads to show their bravery...They weave wood bark into cloth. They esteem tattoos, the rich men have more tattoos and the poor men less, distinguishing the rich men from poor men by how much they have tattoos on the body" (Yue, S. 2007: 3233). The section of “Qiong (琼) State" in the same volume also records that “There are barbarians Wild $L i$ (生黎) ... There are no rites and social regulations and these barbarians should be ruled by force. They live in deep caverns, weaving wood bark clothes and using kapok as thick cotton cloth" (Yue 2007: 3236). The section of “Li Dong (黎峒)" in Vol. three hundred and thirty-one in Textual Research on Historical Narration (Wengxian Tongkao 文献通考) records that “The island of $\mathrm{Li}$ Dong is located in the great sea where can be reached in one day by boat, originally was governed by Qiong (琼) state during Tang Dynasty. There is a Limushan (黎母山) mountain where aboriginal $L i$ people live in...The local woman wears Si Bian (缌绠) cloth made of mixture of hemp, wheat straw, and bark. They wove wood bark into cloth" (Ma, D.L. 2000: II-598). Gu Yanwu (顾炎武) said in the section of "Guangdong" in Vol. twenty-nine in his General Analysis on the Foreign Countries of the World (Tianxia Junguo Libing Shu 天下郡国利病书) that “The short bucked shaped clothes $\mathrm{Li}$ people wear are made of wood bark" (Gu, Y.W. 2012b: 3420).

The work craft of bark clothes making of Taiwan aboriginal was early recorded in literatures of the Sui and Tang dynasties. Vol. eight hundred and twenty of Imperial Encyclopaedia in Taiping Reign cited from Collected Memorandum of Daye Reign (Daye Shiyi Lu 大业拾遗录) written by Du Bao (杜宝) records, “Zhu Kuan (朱宽) returned after conquering the Liuqiu (留仇) state with more than one thousand captured population and other products which were quite different from that of China. People there collected wood bark to make white cloth... Another kind of local cloth was Xiban (细斑) cloth with fine spotted pattern decoration" (Li, F. et al. 2008: book 900-314). The almost similar records are seen in the chapter "Liuqou State (留 仇国)" in Vol. four hundred and eighty-three of Extensive Compilation of Narration in Taiping Reign (Taiping Guangji 太平广记) (Li, F. 1961: 3973), it states that both the bark cloth and Xiban cloth Zhu Kuan saw in Liuqiu was different from the cloth of Huaxia in Central Nation. Professor Ling Chunsheng (凌纯声) said that both the "collected wood bark to make white cloth" and "Xiban cloth with fine spotted pattern decoration" Zhu Kuan saw in Liuqiu were bark cloth and Xiban cloth can be traced to what recorded in the section of "Yizhou" (夷洲) in Biography of the Environment and Product of the Linhai Prefecture (Linhai Shuitu Zhi 临海水土志) written by Shen Yin (沈芗) during the Three Kingdoms (AD 220-265) (Ling, C.S. 1963). Though his opinion taking the Xiban as bark cloth and tracing back to Three Kingdoms maybe not soundly based, the "collected wood bark to make white cloth" obviously is bark cloth work craft of indigenous people.

With the exploitation of Taiwan by the Han people who migrated to the island more and more, the culture of "straw and bark weaving" of aborigines Fan ethnic groups were more widely witnessed and recorded in the Chinese ethnographies since the Ming and Qing dynasties. Early migrants of Han people to Taiwan often saw the mountainous "barbarians" Fan wearing straw skirts and barks clothes, surprised by these "uncivilized" landscapes. Chen Di (陈第) wrote in his Records of East Fan 
Barbarian (Dongfan Ji 东番记) that “Aboriginal people there do not wear clothes in summer and even in winter, women wear straw skirts just to cover their privates" (Chen, D. 1987). In his Traveling Notes Across Taiwan Strait (Bihai Jiyou 稗海纪 游) Yu Yonghe (郁永河) recorded that the blankets which barbarians wrapped themselves in winter were made of wood barks. "Men and women are naked in summer with only a very small piece of cloth to cover their privates. In the winter people cover their bodies with blankets which are made of barks and mixing with dog furs" (Yu, Y.H. 1987: II-33). Chronicle of Zhuluo County (Zhuluo Xianzhi 诸罗 县志) records in the Vol. eight "Custom and Mores" that "the aboriginal peoples in the uplands of Banxian (半线) generally made bark skirts as white ramie cloth... Peoples from Dagewen (达戈纹) to Shuiliansha (水沙连) also made white clothes by mixing bark and ramie decorated with reddish brown lines patterns. People in communities of southern areas generally made grey bark clothes. The aboriginal people used bark clothes as dresses while migrant Han people there used it as a bag for its solidness" (Zhou, Z.X. et al. 1962: 156-157). The third volume of Albums of Minorities and Foreigners' Tributes in Qing Dynasty (Huangqing Zhigong Tu 皇清 职贡图) records the bark cloth cultures in a number of branches of the indigenous people in Taiwan, such as the Civilized Fan (熟番) in Zhuluo (诸罗) county. "Men wore bird feather on heads and long bark clothes on bodies, but usually were naked in summer.” The Wild Fan (生番) in Fengshan (凤山) county, “the indigenous people lived in the slate huts next to the dangerous and difficult cliff area as caverns. Men and women were generally naked or covered with buckskins, while very few rich people wore foreign silk clothes. They also could weave wood bark into cloth." The Wild Fan in Shuishalian (水沙莲) village in Zhanghua (彰化) county, “were generally rich and mostly wore buckskins, bark clothes, and even textile cloth." Another mountainous Wild Fan village in Zhanghua, "aboriginals lived in mountainous caverns, ate raw foot and blooded meat. They were naked in both hot summer and cold winter. The aboriginal female tattooed their cheeks of net pattern and also made bark cloth blanket." The Wild Fan in Naiwu (乃武) village in the right of Tanshui (淡水) County, "the wild barbarian people lived next to the mountain, both man and woman were naked, or wore deer skin cloth and collected wood leaves to make dress" (Fu, H. 1991: 274, 292, 299, 306).

Furthermore, since the Han and Jin (晋) dynasties, the Chinese voyagers sailed from southeast coast of China southward along the Maritime Silk Road and also witnessed and recorded the bark cloth cultures of indigenous people in the Southeast Asia. In the Indonesian archipelago, Vol. one hundred and eighty-enght of General Laws and Regulations (Tong Dian 通典) of Tang Dynasty cited from the Biography of Local Custom of Funan State (Funan Tushu Zhuang 扶南土俗传) written by Kang Tai (康泰) and Zhu Ying (朱应) in the time of Wu (吴) state of Three Kingdoms, "Huozhou (火洲) Island is located to the east of Mawuzhou (马五洲) Island...people there strip wood bark and weave them into cloth....and in the states of Jiaying (加营国) and Zhubo (诸簿国), people also strip tree bark in mountains in March to weave them into Huowan (火烷) cloth" (Du, Y. 1984; Chen, J.R. 2006: 23). The Imperial Encyclopaedia in Taiping Reign records in chapter "Cloth and Costume" of Vol. eight hundred and twenty that "There is a Shuqiu (肃丘) island in 
the sea where mountain fire often combusted in the Spring until Autumn. When fire burns local people strip the bark from the single species tree on the island and weave it as cloth. The bark cloth is brown and people dyed it in wood ash then weave it into coarse cloth, which is poorer than Chinese textile cloth but fire resistant" (Li, F. et al. 2008: book900: 314-315). Similar culture was recorded in the chapter of “Biography of Funan State (扶南国传)" in the History of Liang of South Dynasties (Liang Shu 梁书): “There is a big island in the east sea of Funan (Nokor Phnom), and Zhubo state is located on the island. To the east of Zhubo state...reach Huozhou island on which a species of tree is usually combusted. The island people usually strip the tree barks and weave them into clothes" (Yao, S.L. 1983: 787-793).

Though the indigenous peoples of Southeast Asia were complex and mixed in last thousands of years, they had been closely related to the ancient Bai Pu and Bai Yue cultures of Southern China, in the "South of the South" of the ancient Chinese civilization. The work craft of "stripping tree barks and weaving into cloth" witnessed by Han people in Southeast Asia were closely related to the indigenous bark cloth culture in Southern China, with connection in geographical distribution and the same craft technology in regional cultural history.

In a nutshell, the culture of the bark cloth of the indigenous people of Southern Man or Bai Pu and Bai Yue system in South of China and Southeast Asia was very different from the so-called "Clothing and Dressing Civilization" of Huaxia in the Central Plains in the North, described in Chinese historical literatures. For the lacking of their own historical records, the indigenous people had been recognized as "hetero-culture" in Huaxia and Han national discourse with strong Sinocentrism, and these non-woven cloths of "straw clothing and bark weaving" was usually listed together with the other "uncivilized" features in these records, such as "cutting hair without hairpin", "tattoo and naked body", "dwelling mountainous caverns" and "eating raw and blooding meat". But these records are important references for us to understand the long history of cloth culture of the indigenous people in Southern China and Southeast Asia.

\subsection{Ethnographical Investigation to the Indigenous Straw and Bark Cloth Making Craft in Asia-Pacific}

From the "straw and bark clothing" of Island $Y i$ in early history of China, to indigenous Taiwanese "bark weaving" in the Qing Dynasty, as well as "stripping tree barks to weave cloth" of Southeast Asia, the historical information presents the preliminary distribution and recognition of bark cloth cultures in Southern China and Southeast Asia. However, these records of "straw cloth and bark weaving" of southern "barbarian" people on the hetero-cultural perspective of Huaxia and Han nationality presented only a word or two and lacking the detailed depiction of their bark weaving technology. The ethnographical investigation on the modern work craft of bark cloth making of Amis Tribe in Taiwan, Dai ethnic in Yunnan, Li in Hainan island, Bru-van kieu in Vietnam, Austronesian in West Samoan, and others in the Pacific islands, truly revealed the connotation of this historically distinctive heritage. 
The cultural heritages of bark cloth of Taiwan aboriginals were commonly investigated in modern ethnographies. In the 1930s, Professor Lin Huixiang collected three kinds of aboriginal costumes in Taiwan, linen, beast coat, and barks. Among the barks included coconut bark, banana bark, and so on. In his researches on the material cultural history of Taiwan aboriginals, Professor Liu Qiwei (刘其 伟) also recorded that "the clothes of aboriginal people in the past were mostly made of hand-woven linen or banana barks, and some others were made of leather" (Lin, H.X. 1930; Liu, Q.W. 2004: 124). In 1948, Ms. Ling Manli (凌曼立) made an investigation in Matai'an (马太鞍) village of Hualian (花莲) county, and the chief Unak Tabon (何有柯) of Amis tribe told her the bark cloth making skills he saw when he was young. That is, the aboriginal people chose the kind of tree paper mulberry (楮树), the Broussonetia papyrifera, as bark material, used large stone knives to cut the tree log, small stone knives and aboriginal knives to strip barks, oval stone hammers and wooden beaters of various shapes and sizes to beat the bark, then made products of headscarves, sleeveless coats, sleeves, long skirts, waist skirts, front coverings, quilts, cushions, straps and so on with the bark cloth. This is one of the most detailed cases of bark cloth making craft recorded in modern ethnography of Taiwan (Ling, M.L. 1963). In the summer of 2008, the author made a one-month ethnographical investigation of the aboriginal cultures in mountainous areas in Taiwan, visiting 35 tribes in 10 aboriginal societies of Atayal (泰雅), Thao (邵), Bunun (布农), Tsou (邹), Paiwan (排湾), Rukai (鲁凯), Puyuma (卑南), Amis (阿美) and Saisiyat (赛夏). Among a series of new ethnographic discoveries, the work craft of bark cloth of Amis ethnic in Adulan (都兰) tribe, Donghe Town, Taidong county was a significant one (Wu, C.M. 2009).

The name of Adulan or Etolan (都兰) tribe originates from 'atol, meaning "piled stones", "stone wall" and "overlapping stone wall". It is on the east side of Adulan mountain with a population of nearly 1500 people and more than 400 families, a traditional big tribe of Amis ethnic. In the famous Adulan site between the eastern foot of the mountain and the west side of the village, 18 Megalithic stone carvings of Qilin (麒麟) Culture, including sarcophagus, stone walls, and figurine monolithic, were discovered. Adulan site is regarded as the birthplace of Amis ethnic culture, and the origin of the name of Adulan tribe. People of the tribe belong to Puyuma (卑南) group of Amis whose ancestors originated in Arapanay village in the south of Zhiben (知本), then successively migrated to Chulu (初鹿), Changbin (长滨), Xingang (新港) and other places, and finally settled in Adulan village.

The author witnessed the work craft of bark cloth making in Panay Talikong Fang, an indigenous craft workshop founded by Panay (巴奈), the chiefs of Adulan tribe, his Chinese name is Shen Taimu (沈太木), and his wife Ashao's Chinese name is Pan Xiuzi (潘秀仔). They set a traditional craft showroom in both the workshop and their home, and Panay showed us the whole process of bark cloth making and its products (Figs. 6.1 and 6.2).

The first step is to choose and collect the bark wood. Amis people often use a kind of tree called Rolang (落浪) as the raw material for making bark cloth, which grows everywhere in Taitung mountainous areas. Rolang actually is a kind of paper mulberry, with scientific name Broussonetia papyrifera, a deciduous tree of a 
a

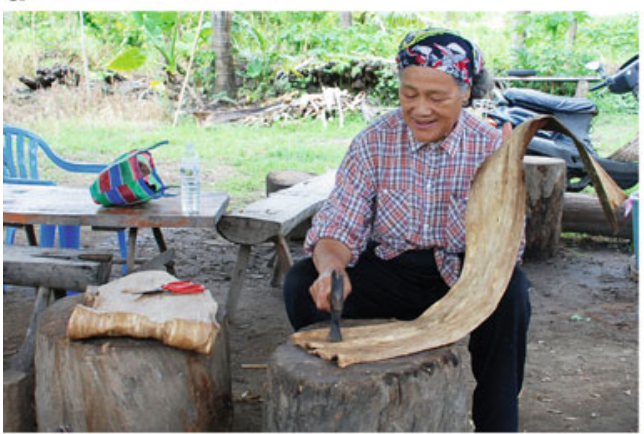

C

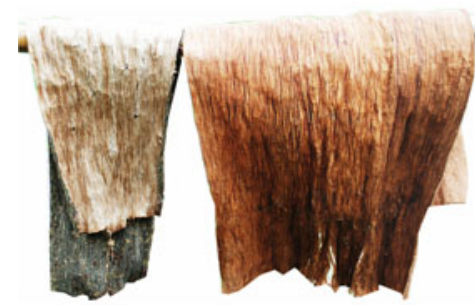

e

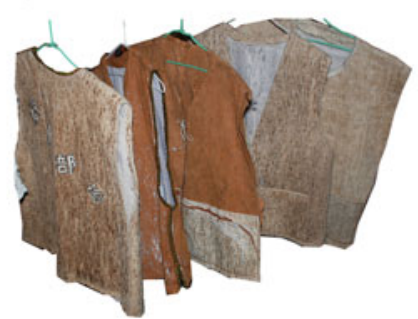

d b
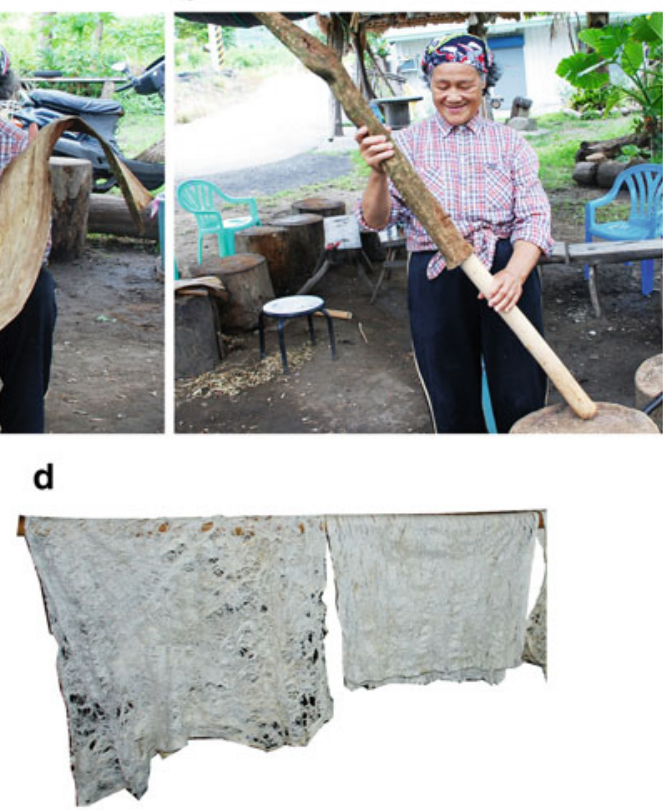

f

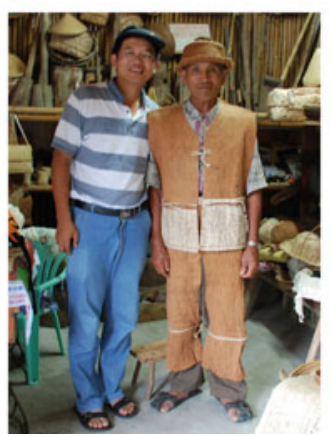

Fig. 6.1 The bark cloth making craft in Adulan tribe of Amis ethnic, Taiwan

variety of moraceae with some different local names at low and moderate elevations in south China, Southeast Asia, and the Pacific islands. Amis people also choose another kind of deciduous tree called Yono (约那) with scientific name Ficus superba and the native name Bird Banyan or Red Banyan. The fibers of these two kinds of trees are quite ductile, suitable for making bark cloth. After they found the trees for beating bark, they cut them into logs of right size.

The second step is to strip barks. A wooden hammer is used to tap the bark of the logs to loosen it so that it is easy to be stripped off. 
Fig. 6.2 The bark cloth stone beaters of Panay Talikong Fang
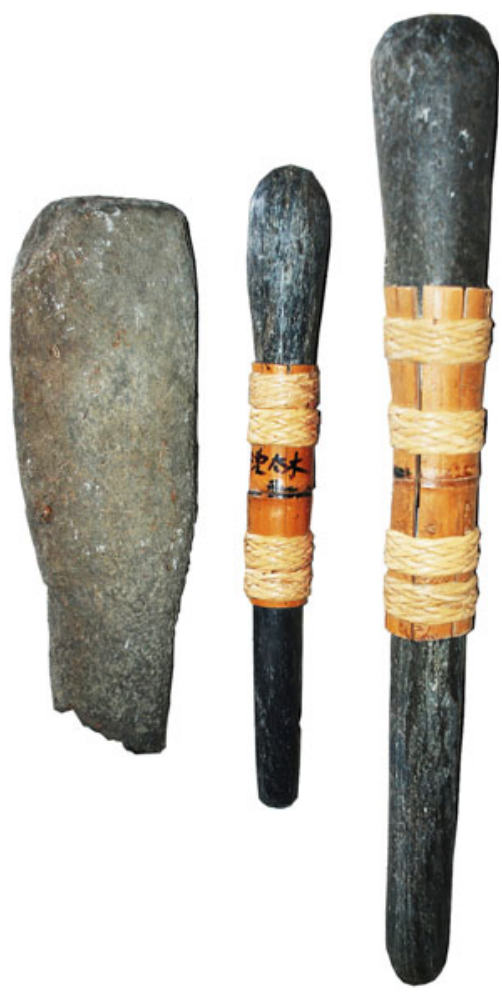

The third step is to soak barks. The stripped barks are soaked in water to make them more ductile and softer for further beating.

The fourth step is to beat barks. The soaked bark is flattened out on the platform made of stumps and beaten repeatedly with iron and stone beaters of different shapes and sizes. The surfaces of these iron beaters are carved into different patterns such as gridding and concentric circles. The repeatedly beating works remove the resin from the barks, extending and compacting the fibers of the bark to form a larger and softer piece of bark cloth.

The last step is tailoring. After bark cloth is finished it becomes the materials for making dresses and hats. The bark cloth products of Panay's workshop include a variety of coats, pants, hats, bags, and so on. For the changing of ethnic culture, Amis people no longer wear bark cloth products in daily life, so they mainly sold them to tourists as ethnic handicrafts.

As an aboriginal ethnic group in the mountainous areas in the eastern coast of Taiwan, Amis is the only ethnic preserving the bark cloth culture seen so far in the aboriginal communities. The bark cloth making craft in the workshop of chief Panay is a very precious ethnographic heritage for understanding the connotation and development of the bark cloth cultural history of Taiwan and Asia-Pacific 
regions. Anyway, Panay's work craft of "bark weaving" is in fact not a direct cultural inheritance from ancient times, but a case of traditional cultural revival and reconstruction of indigenous people in the background of "Aboriginal Movement" in the last half century. These indigenous cultural reconstructions including Panay' workshop aims at restoring the traditional cultures of the indigenous people which were lost in the Japanization in the first half of last century, and the sinicization of mountainous aboriginals after "Recovery of Taiwan". Nevertheless, Panay's reconstruction and imitation of the Amis bark cloth making craft was revived according to its deep historical and cultural background. Chief Panay memorized the bark cloth making and wearing story of his grandfather when he was a child, which coincides in line with historical records of "bark weaving" and "making bark for skirts" of aboriginal Fan in the Qing Dynasty.

In addition to Amis ethnic group in Taiwan, there are also a number of ethnographic heritages of bark cloth cultures in the south of mainland China. The southwest mountainous regions of Guangxi, Yunnan, and Guizhou plateaus have been the original lands of mixed indigenous ancestors of Bai Pu and Bai Yue people since the prehistory. Bai Yue people in this region varied in a few branches such as Dian Yue (滇越), Yi Yue (夷越) and Teng Yue (腾越), and the westward migration of the branches of Western Ou (西瓯) and Luo Yue (骆越) after the Han and Jin dynasties. With the movement of "Suppressing the Southwest Barbarians Yi" of Han Dynasty and the sinicization of Bai Yue and other indigenous peoples, the descendants of Bai Yue people in this periphery region of the empires had changed and evolved into a number of modern minorities of Zhuang Dong (壮侗, Kam-tai) language family, such as Dai (傣), Buyi (布衣), Dong (侗), Shui (水), Zhuang (壮) and so on, which accumulated a large number of unique cultural features of $B a i$ Yue. The bark cloth culture of Dai people in Xishuang Banna (西双版纳) of Yunnan is one of these distinctive cultural heritages. The Dai people there preserve the complete work crafts of bark cloth making. After choosing the tree logs, they used a special wooden hoe to strip off barks, and then repeatedly beat the bark with a large wooden hammer and soaked bark in water until it was slapped into a piece of soft, stretched bark cloth. After that the bark clothes were sewn into hats, jackets, trousers, felts, carpets, cushions, quilts, and other products (Fig. 6.3).

The bark cloth culture of minority $L i$ (黎) ethnic in Hainan island still exists in Sanya (三亚), Wuzhishan (五指山), Dongfang (东方), Qiongzhong (琼中), Baoting (保亭), Lingshui (陵水), Ledong (乐东), Changjiang (昌江), Baisha (白 沙) and other counties. The bark cloth made by $L i$ people is called Nabu (纳布), Chupi (楮皮布) and Gupi (谷皮布) clothes, the main steps to make are stripping, trimming and soaking the barks in water to remove the resin, rinsing, drying and beating the barks into clothes. Then the bark cloth can be cut to make pillows, quilts, hats, coats, skirts, and alike. The Ethnological Museums of $L i$ in Lingshui, Baoting, Tongzha (通什), Baisha, Changjiang and other counties display bark cloth products made by $L i$ people.

Vietnam is one of the few regions in Southeast Asia of ethnographically preserving the bark cloth cultural heritage. The vast majority among 50 ethnic groups in Vietnam are Viet-Muong (越芒) language family, of which the Kinh (Viet) people 
a
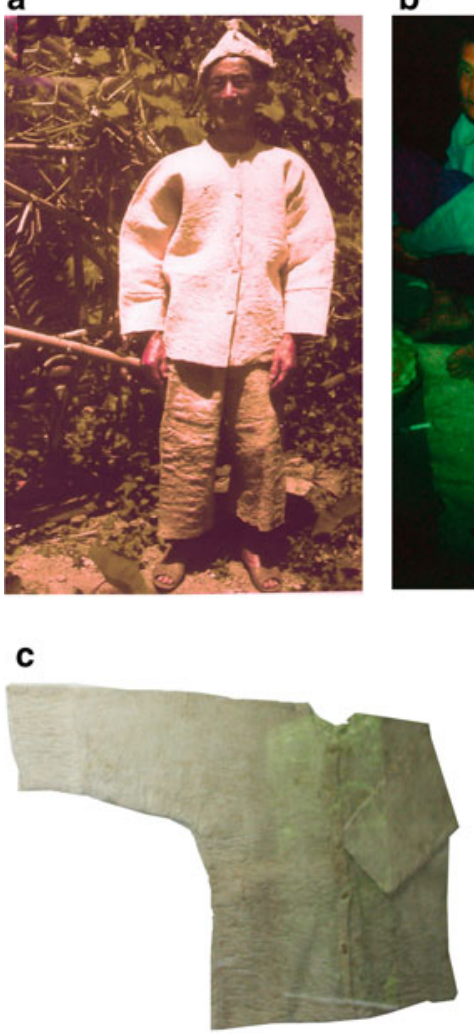

b
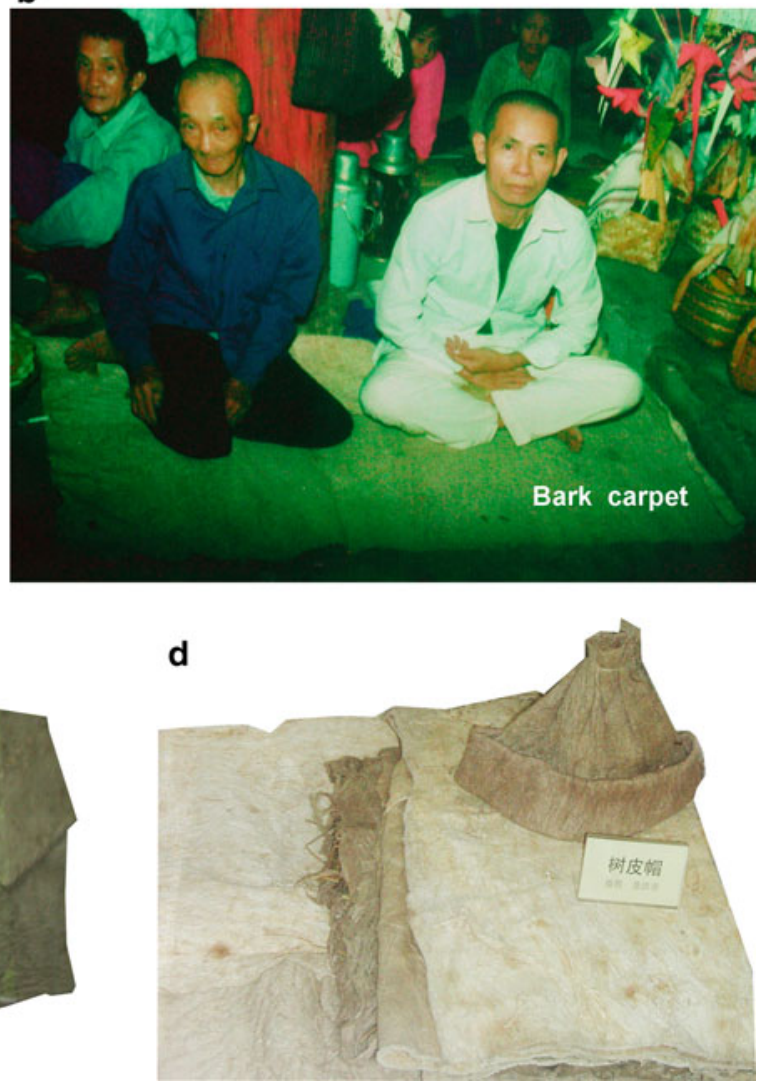

Fig. 6.3 Bark cloth products of Dai ethnics in southwestern China (Xishuang Banna Museum of Yunnan)

composes nearly $90 \%$ of the population of the whole country, which are the descendants of Luo Yue branch of ancient Bai Yue indigenous cultural system living in the north and central Vietnam. In addition, in the south and central Vietnam are Cham (占) people of ancient Indonesian descendants who speak Austronesian language. The work craft of bark cloth making still exists in Bru-van Kieu ethnic group who live in the central mountain area and is identified as Mon-Khmer group in Austroasiatic language family. The bark cloth making process of Bru-van Kieu is very similar to that of the Dai people in Yunnan of China. After striping bark from the wood with the back of a knife, the bark is soaked in the water for 10 days, dried, beaten into soft barks cloth, and then was made into hats and costumes (BTDHVT 2006: 14-15; Nguyen, Y.H. 2004: 19-22).

So far the most exquisite and fully developed skill of bark cloth making craft in the world was the Austronesian bark cloth culture-the tapa of indigenous Melanesia and Polynesian in the Pacific Ocean. Austronesian craft of bark cloth 
tapa making was preserved until quite recently, Roger Neich and Mike Pendergrast, the honored ethnologists at the Auckland Museum of New Zealand, surveyed in West Samoan Islands in 1980 and recorded fascinating scenes of the Samoan tapa, the Siapo making. Most West Samoan preferred using Broussonetia papyrifera to make tapa cloth and some chose breadfruit (artocarpus) and banyan (wildfocus) trees. In making tapa the indigenous woman stripped the bark off the tree log and scraped off the outer layer of the bark with blades and shells to preserve the inner fiber layer, then laid the bark flat on a wooden anvil, beat it hard with wooden club beaters with grooved or smooth facets until a piece of soft bark cloth was made. The decoration of Samoan tapa was made by either freehand painting on the cloth or imprinting on a wooden carved tablet Apeti with variant geometric patterns to make fine intricate decorations. The perfection and exquisiteness of the Pacific bark cloth tapa are fully reflected in the types and patterns of the tapa dress, which are based on natural elements such as parallel lines, squares, grids, twists, water ripples, turns, parallel lines with triangular filling, triangle with square filling, back filling rhombus, branch shape, banana leaf shape, four to eight petal pattern, four or eight leaf swirl pattern, solar pattern, as well as a small number of birds, animals, fish images and complex combination of patterns (Neich, R. et al. 1997: 12-15).

Before Euro-American navigators, missionaries and anthropologists arrived the Pacific Islands in the seventeenth century, the indigenous bark cloth tapa, hula straw skirts, feather, and shell decorations were the representative costumes of the Austronesian societies, lasting for hundreds or more than thousands of years. The upper society of indigenous Austronesian wearing and posing in nice tapa costumes were also shown in the works of European painters and photographers, presenting precious images for understanding the tapa culture in Pacific in the last hundreds of years. Honolulu Art Museum in Hawaii keeps a paint of Queen Kahumanu, the wife of the king of Hawaii Khamehamehai I, by Louis Choris between 1816 and 1817, on which Queen Kahumanu is elegant in her tapa apron with beautiful geometric patterns. Dunedin Museum in New Zealand keeps an old photograph, taken in 1859, of the young couple of Tonga Sheikh who also dressed in elegant geometrically patterned tapa skirts. A British publisher in London collected an old photograph of a late nineteenth century Fijian samurai in tapa suit holding a samurai stick in hand (Barrow, T. 1972: 31, 64, 83, 85). The old photo gallery in the city of Apia, the capital of Samoa, also keeps a beautiful portrait of a late nineteenth century Samoan girl in a tapa cloth dress with finely printed geometric patterns (Neich, R. et al. 1997: 11). Now a number suits of elegant tapa cloth garments of Pacific people are exhibited in Euro-American museums, such as Hawaii, Chicago, New York, Boston, and Wellington, showing exquisite craftsmanship of tapa making of Austronesian (Figs. 6.4 and 6.5).

It can be seen that historical indigenous bark cloth cultures in southern China, Southeast Asia, and the Pacific have sufficient "remnants" in contemporary ethnographies. Amis, Dai, Li, Bru-Van Kieu, Pacific Austronesian and other indigenous cultures share basic commonness of bark cloth making skills, including the bark material choosing and collecting, tool variants, bark stripping and beating, costumes tailoring, and other links. They are generally integrated within the 

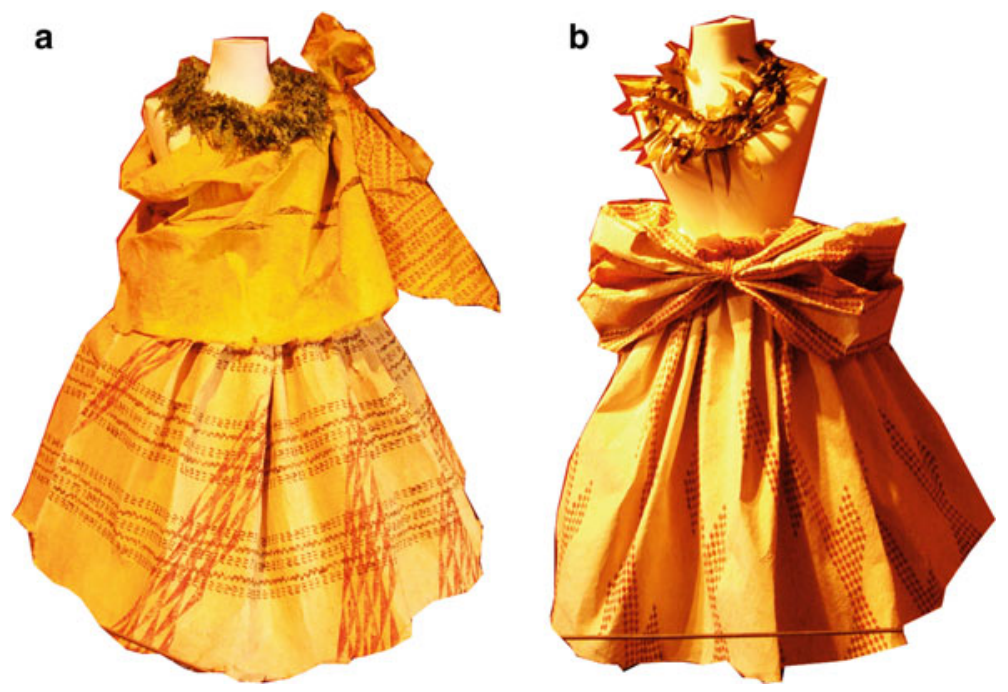

Fig. 6.4 Suits of tapa cloth apron garments of Pacific (Bishop Museum of Hawaii 2006)
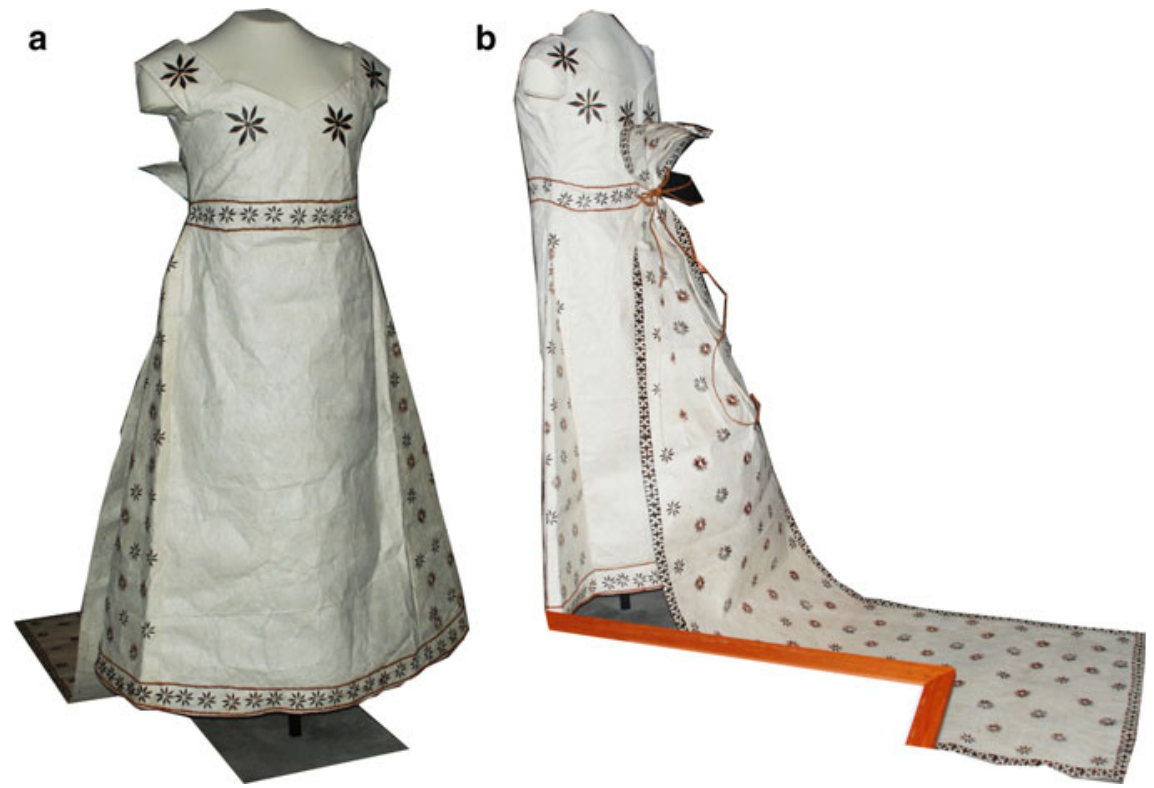

Fig. 6.5 Bark cloth wedding dress of Austronesian (Field Museum of Chicago 2017)

indigenous cultures of ancient Bai Yue-proto-Austronesian, confirming the historical connection and cultural community in Asia-Pacific region. The considerable differences among these regional bark cloth cultures are manifested in the 
simplicity, crudeness, and primitiveness of native bark cloth kills and products in South China and Southeast Asia, such as that of Amis, Dai, Li, Bru-Van Kieu peoples, and the complexity, exquisites, and maturity of Austronesian tapa in the Pacific islands, reflecting the potentially logical evolution of bark cloth cultures and its dissemination from the Maritime Region of Southeast Asia to the Pacific Islands.

\subsection{Archaeological Investigation and Research on the Bark Cloth Beaters}

As a special kind of material culture, bark cloth remains are very difficult to be preserved and discovered in archaeological sites. Therefore, archaeologists recognize and reconstruct the prehistoric and ancient bark cloth cultures in the Asia-Pacific regions mainly through the investigation of the tools for bark cloth making, especially the identification, typology, and chronology of stone beaters for bark cloth.

The earliest bark cloth stone beater was identified by French archaeologist M. Colani in a prehistoric site on the Indochina peninsula, and later American archaeologist H. Otley Beyer found similar stone beaters in late Neolithic sites such as Batangas, Rizal, Bulakan, Cavit, southern Cebu, and Cotabato in the Philippines. According to Beyer's research, there are three types of bark cloth stone beaters in the Philippines, the straight-backed handle type, the horned handle type, and the type lacking a stone handle. He also held that non-handle stone beaters appeared later than handle stone beaters. Among them, horned handle bark cloth beater was unique to the Philippines, known as "Philippine-type bark cloth beater" (Beyer, H. O. 1948: 58-61).

The discovery of the bark cloth stone beaters in southern China began with prehistoric archaeological investigation in Taiwan. As early as the time of Japanese occupation archaeologists N. Utsurikawa (移川子之藏) and N. Miyamoto (宫本延 人) discovered a kind of slate beater with parallel-grooved in the sites of Keelung (基隆) and Su'ao (苏澳), known as "grooved beater" and "kitchen knife-shaped beater". Because these early discoveries were similar in shape to the wooden club used for making stamped pottery in the aboriginal Bunun (布农) tribe, they were once regarded as the pottery making stamper. Later, T. Kano (鹿野忠雄) compared these implements with similar ones in the Philippines and then identified them as bark cloth beater, the tool for making bark cloth (Kano, T. 1995: 313-321). After that Professor Ling Chunsheng also confirmed the functions of "stone bark cloth clubs" and "bark cloth stone beaters" found in prehistoric sites such as Kanding (嵌 顶) in Tanshui (淡水), Yuanshan (圆山) in Taipei (台北), Shuiweixi (水尾溪) of Dajia (大甲) in Taichung (台中), Xiaogangshan (小岗山) in Kaohsiung (高雄), Beinan (卑南) in Taidong of Taiwan (Ling, C.S. 1963: 185-187). After the recovery from Japanese colonization more stone beaters of this type have been discovered in Taiwan's prehistoric sites, and professor Lien Chaomei (连照美) once collected 23 pieces of such "grooved stone beaters" in an early research, 
including 13 handled beaters and 8 non-handled beaters, as well as 2 fragments, and made a typological research. However, she was quite cautious about their function and doubted the recognition of both "bark cloth beater" and "pottery making stamper" until the sufficient archaeological evidences (Lien, C. 1979).

In mainland China, the remains of bark cloth stone beaters have been discovered mainly in Zhejiang, Fujian, Guangdong, Hong Kong, and other coastal areas of southeast. Professor Ling Chunsheng pointed out that the bark cloth stone beaters respectively found in the "Neolithic" Liangzhu and Gudang (古荡) sites in Hangzhou of Zhejiang in the 1930s and in "Neolithic" sites in Guangze (光泽) and other places in Fujian in the 1950s, varied with the straight back handled type, the kitchen knife shape handled type and the non-handle composited type. He considered that all of these stone beaters were plain-faced without grooves, which should have been more primitive pattern and earlier than the same type of beaters found in Taiwan and the Philippines (Ling, C.S. 1963: 188-190). In Fujian, at Huangqianshan (黄乾山) site of Pinghe county, Tudigong Anshan (土地公垵山) site of Nanan (南安) county and other sites of Shang and Zhou dynasties in south of Fujian, the non-handle composited stone beaters of rounded square with carved grooves were collected. The coastal area of Guangdong is the most concentrated area of discovering the bark cloth stone beaters in the south of mainland China. At Wanjiaozui (万角嘴), Hudiwan (虎 地湾), Yonglang (涌浪) sites in Hongkong, Dameisha (大梅沙), Dahuangsha (大黄 沙), Xiangtouling (咸头岭), Caotangwan (草堂湾), Gongbei (拱北) sites in Zhuhai, Longcao (龙穴), Shuiyong (水涌) and Xiasha (下沙) sites in Zhongshan and other Neolithic sites of Tai Wan Culture (大湾文化) five or six thousand years ago in Guangdong, various kinds of non-handle composited stone beaters of rectangle, square, rhombus, round shapes and so on, with carved grooves, have been discovered (Tang, C. 2000, 2003; Tang, Maya, H. et al. 2019).

Furthermore, following the pioneering work of M. Colani at the beginning of the last century, there have been a lot of new discoveries of bark cloth stone beaters in the Neolithic sites of the Indo-Chinese Peninsula since the 1960s. In the Phung Nguyen Culture of north Vietnam about 4000 years ago, 19 pieces of non-handle composited stone beaters of rectangle shape with two facets-grooved were reported. These beaters have been misinterpreted as "grooved grindstone" before Vietnam's famous archaeologist Ha Van Tan (何文瑨) recognized them as beaters for making bark cloth (Ha Van Tan 2003). Besides, 8 bark cloth stone beaters of rectangular type with carved grooves dating from prehistory to historical periods were also discovered in Thailand (Amara Srisuchat 2003).

In short, in the archaeology of the Asia-Pacific region so far, there are further discoveries of bark cloth stone beaters, and their spatial distribution is basically consistent with that of the "Straw and Bark Woven Clothing" cultures of the indigenous peoples of southern China and Southeast Asia recorded in the historical and ethnographical literatures. Based on the morphological function of the bark cloth beaters recorded in the ethnographies of Southeast Asia and the Pacific, Professor Tang Chung divides the bark cloth beaters found in south China and Southeast Asia into two types: composite type without handle and club type with handle, proposing the evolving sequence of prehistoric bark cloth beaters in this region developed from 
composite type to club type according to typological and chronological data (Figs. 6.6 and 6.7). Specifically, the earliest bark cloth stone beaters were the remains of Tai Wan Culture around the estuary of the Pearl River Delta dating to 60005000 years ago, and then the beaters of Phung Nguyen Culture of northern Vietnam from 40,000 to 3500 years ago. In Thailand and the Malay Peninsula, the Philippines, Taiwan, and other places, the prehistoric bark beaters were no more than 3500 years ago, and the Oceania Islands were later than 3500 years ago, which should be the result of prehistoric cultural spread along the coast of and across the South China Sea (Tang, C. 2000, 2003; Tang, Maya, H. et al. 2019). The archaeological discovery and chronology of bark cloth stone beaters recurs the origin of bark cloth culture in south China and its spreading to Southeast Asia and the Pacific islands, confirming the indigenous ethnic relationship between the ancient Bai Yue and proto-Austronesian.

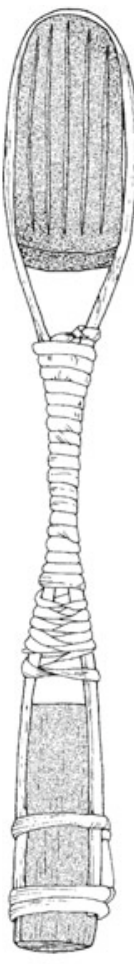

1

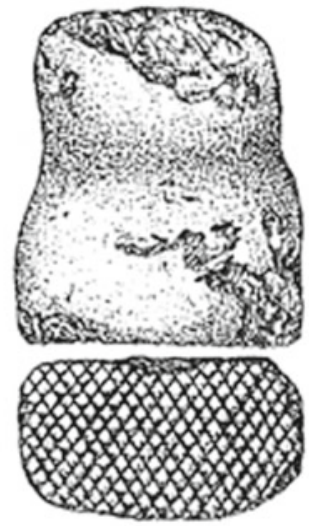

2

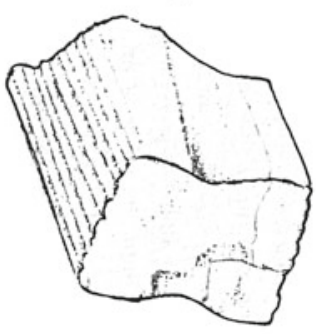

3

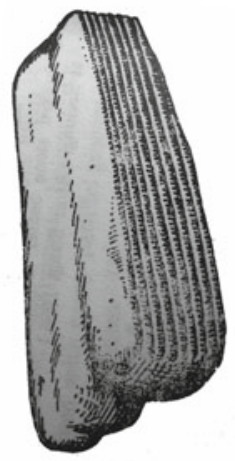

4

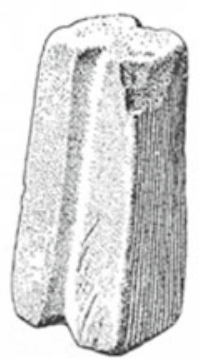

5

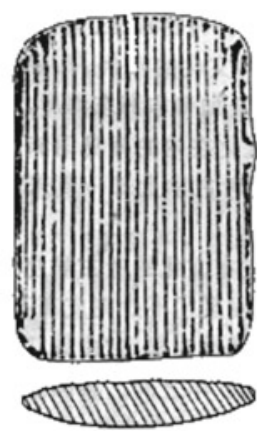

6

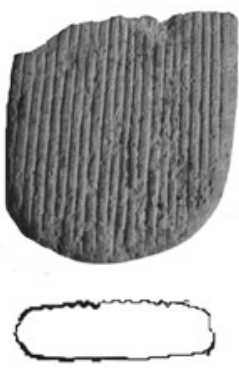

7

Fig. 6.6 Composite type (without handle) tapa beaters in South China and Southeast Asia (1. Sulawesi ethnography. 2. Surat Thani in Thailand. 3. Go Bong site of Phung Nguyen Culture in northern Vietnam. 4. Baishui 白水 in Tainan of Taiwan. 5. Cebu of Philippines. 6. Pearl River Delta of Guangdong. 7. Tudigong Anshan Mount 土地公垵山 in Nan'an 南安 County of Fujian) 


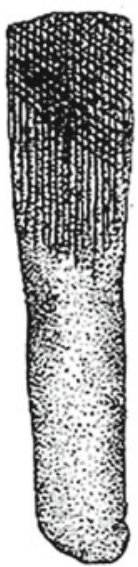

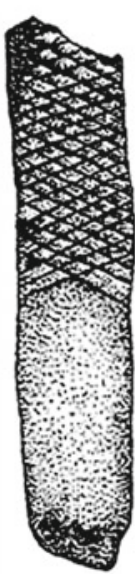

1
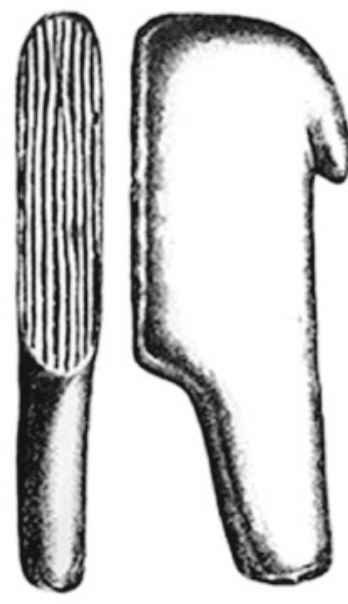

2

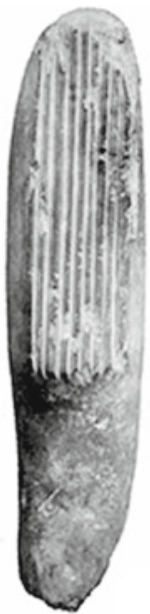

3

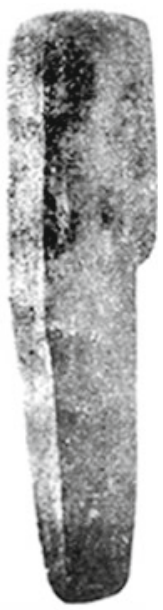

4

Fig. 6.7 Club type tapa beaters in South China and Southeast Asia (1. Nakhon Si Thammarat in Thailand. 2. Luzon of Philippines. 3. Tapenkeng of Taiwan. 4. Liangzhu of Hangzhou in Zhejiang)

The Pacific islands are the far reaches of bark cloth cultures along the land-sea dissemination of Asia-Pacific region. In contrast to the large number of bark cloth stone beaters in archaeological discoveries in southern China and Southeast Asia, the discovered and identified bark cloth beaters of the Pacific indigenous people are mostly made of hard wood, while their club shape and grooved pattern are similar to the handled stone beater in southern China and Southeast Asia. The oldest bark cloth cultural relic discovered in the Pacific Ocean is the wooden club beater on the Huahine island of Society Islands in French Polynesia, dating from 1100 to 700 years ago. The bark cloth wooden club beaters dating to 400-300 years ago were also found in Waikato of New Zealand (Neich, R. et al. 1997: 9-15). The Bishop Museum in Hawaii possesses a large collection of such club-shaped wooden bark cloth beaters emblazoned with geometric patterns of gridding, stripes, leaf veins, zigzag lines, and alike, which coincide fully in line with the exquisite stamped patterns of the tapa costumes of Pacific shown on the ethnographically painting and photographing of European since seventeenth century.

\subsection{Conclusion}

The non-woven bark cloth originated and early developed in southern China, Southeast Asia and spread in the Pacific Islands, was a distinctively cultural heritage of ancient Bai Yue ethnicities and Austronesian. The sporadic records of "Straw and Bark Woven Clothing" of "Barbarian" Southern Man, Island Yi, 
Bai Yue and Maritime Fan in Chinese historical documents, the ethnographical heritages of bark cloth making crafts of minorities ethnicities of Amis, Dai, Li, Bruce-van Kieu and Austronesian, and the archaeologically discovered bark cloth beaters, have contributed together in depicting the cultural circle of indigenous straw and bark clothes in the maritime region of Asia-Pacific, revealing again the cultural connection between Bai Yue ethnicities and proto-Austronesian during prehistory and early history.

Open Access This chapter is licensed under the terms of the Creative Commons Attribution 4.0 International License (http://creativecommons.org/licenses/by/4.0/), which permits use, sharing, adaptation, distribution and reproduction in any medium or format, as long as you give appropriate credit to the original author(s) and the source, provide a link to the Creative Commons license and indicate if changes were made.

The images or other third party material in this chapter are included in the chapter's Creative Commons license, unless indicated otherwise in a credit line to the material. If material is not included in the chapter's Creative Commons license and your intended use is not permitted by statutory regulation or exceeds the permitted use, you will need to obtain permission directly from the copyright holder.

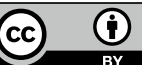

